EISSN: 2706 -7947 ISSN: 2077- 4613

DOI: 10.36632/mejas/2021.11.1.11

Journal homepage: www.curresweb.com

Pages: 153-164

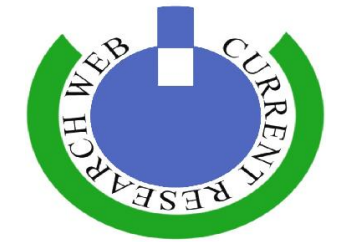

\title{
Assessment of AquaCrop Model in Simulating Wheat Crop Water Use and Productivity in Middle Egypt
}

\section{Nematallh Y.O. Mokhtar and Amira A. Kasem}

Soils, Water \& Environment Research Institute, ARC, Egypt

\author{
Received: 15 December 2020 Accepted: 05 February $2021 \quad$ Published: 20 February 2021
}

\begin{abstract}
The high cost of applied research and the effect of many environmental parameters limiting yield production encouraged researchers to develop and implement empirical models able to simulate and predict crop yield close to that obtained under field conditions. The Food and Agriculture Organization (FAO) AquaCrop model is one of these models. It was calibrated and validated for its ability to simulate growth, biomass and grain yields and crop evapotranspiration of wheat (Misr 2 cultivar) using two-year observed data of a field experiment conducted on clay soil under Giza (middle Egypt) condition during 2018/2019 and 2019/2020 seasons. The effect of three irrigation intervals ( $\mathrm{I}_{1}: 21$ days; $\mathrm{I}_{2}: 28$ days; and $\mathrm{I}_{3}: 35$ days) on wheat yield and its components and on some water relations was tested. After model calibration/validation processes, four sowing dates (10 and 25 November, 10 and 25 December) with four irrigation intervals and one deficit irrigation treatment were used as scenarios for adaptation study. The root mean square error (RMSE), coefficient of determination $\left(\mathrm{R}^{2}\right)$, and percentage difference (Pd) statistical parameters were used to evaluate the model performance. Results revealed that the predicted data by AquaCrop were in close agreement with the measured data. The observed values were within 90 to $99 \%$ of the predicted values in the 1 st season, and within 91 to $100 \%$ in the 2 nd season. Statistical analysis results showed a strong linear relationship between the simulated and the measured data under different irrigation interval treatments in both seasons. The best-fitting model result was obtained with growing session duration with average values of two seasons for $\mathrm{R}^{2}(0.98), \operatorname{RMSE}(5.23$ days) and $\operatorname{Pd}(0.98 \%)$ followed by the simulated biomass yield with values of $0.97,363 \mathrm{~kg} \mathrm{ha}^{-1}$ and $0.99 \%$. The corresponding values of grain yield were $0.94,355 \mathrm{~kg} \mathrm{ha}^{-1}$ and $0.95 \%$, respectively. The crop water use values were $0.95,35 \mathrm{~mm}$ and $0.91 \%$. The results of adaptation study showed that increasing soil moisture content increased simulated aboveground biomass, grain yield and ET crop. Results indicated also that sowing wheat cultivar Maser 2 at Giza region from 10 to 20 November with irrigating crop every 28 days maximize yield and save about $16.3 \%$ of irrigation water. The overall results based on extensive validation of the model indicated that AquaCrop is a valid model and can be used with a reliable degree of accuracy to predict wheat yield.
\end{abstract}

Keywords: AquaCrop, simulation and adaptation, irrigation interval, sowing date, wheat simulated yields

\section{Introduction}

Wheat is produced in Egypt as the most important strategic winter crop by about 4.3 million farmers, which is the main component of subsidized bread. The total cultivated area of 3.8 million acres all of which are irrigated, products amounted to approximately 8.77 million metric tons in 2018 , with an increase of $1.48 \%$ from the preceding year. Despite the scale of production, and due to the rapid increase of population, the production of wheat does not meet the county's demands (McGill et al., 2015). Therefore Egypt imports 11-12 million tons of wheat annually (Isin and Panos, 2017)'s annual brief). The main target of the agriculture sector is filling the gap between production and consumption 
by increasing production which will lower imports, save foreign exchange (Shideed et al., 2010). The agriculture sector accounts for about 86\% of Egyptian water use (FAO 2017).

Water availability one of the most binding constraints to increased crop production, and it is increasingly scarce as urbanization and industrialization compete with agriculture for water use (El Kharraz et al., 2012).Various studies have shown that one of the promising irrigation strategies may be deficit irrigation combined with economic crop production (Fereres and Soriano 2007; Farre and Faci (2009) and Geerts and Raes, 2009). Although this inevitably results in crop water stress and yield depression, high yield can still be obtained by supplying the required amount of irrigation water according to suitable irrigation frequency (interval days) to sensitive crop growth stages, The time interval between irrigation applications is a crucial factor for irrigation management due to it affects soil-moisture distribution, root distribution, water uptake by roots, and water percolation under the root zone Wang et al., (2006). For these reasons, crop yield and WUE depend on irrigation interval days and can thus differ even for the same total amount of irrigation. Irrigation frequency can change the spatial distribution of soil moisture and soil-water storage Cao et al., (2003). High-frequency (once every three days) under drip irrigation produced higher soil moisture in the 0-20 cm soil layer than in the deep soil layer, whereas low-frequency (once every10 days) favored water infiltration and lateral infiltration deep Liu et al., (2011).

Compiling many cultivation practices i.e. the sowing date with irrigation frequency and crop varieties maybe lead to enhancing growth conditions and increases final production. In this respect, Meena et al., (2016) reported that wheat productivity irrigated with a moderate amount of water can be increased substantially by adjusting the sowing date to optimum atmospheric temperature for variety cultivated.

The crop growth models have been successfully used for decades to inspect crop responses to environmental stresses and to test alternate management practices by researchers around the world (Stockle et al., 2003. ; Behera and Panda, 2009. and Steduto et al., 2009). The AquaCrop model (Raes et al., 2009; Steduto et al., 2009) was developed by the Land and Water Division of FAO to assess the effect of environment and management on crop production and simulates yield response to water use by crops. It is particularly suited to address conditions where water is a key limiting factor in crop production, which it helps the making decision and devising strategies for efficient management of crop-water productivity. In addition, AquaCrop simulates soil evaporation and crop transpiration explicitly as individual processes. The advantage of this model is that, maintains a balance between robustness and output accuracy with a minimum of input data as a generic crop water productivity (WP) model (Raes et al., 2009). However, due to various parameters of the culture and some are not universal, the model must be adjusted to local conditions, cultivars, and to different crop management practices to make it globally applicable. Many calibrations and performance evaluations have been done for wheat by Neha et al., (2017) in India, Jin et al., (2014) China. Andarzian et al., (2011) in Iran, Mkhabela and Paul (2012) in Canada and Toumi et al., (2016) in Morocco.

The aims of the investigation were to: 1) evaluate the accuracy of the AquaCrop model in predicting the effect of three irrigation intervals (I1: 21 days; I2: 28 days; and I3: 35 days) on wheat biomass and grain yields and on some water relations, and 2) test the effect of different adaptation scenarios (four sowing dates: 10 and 25 November and 10 and 25 December) and five irrigation treatments on maximizing wheat yield, saving irrigation water, and optimizing water productivity under Middle Egypt (Giza region) conditions.

\section{Materials and Methods}

\subsection{The field experiment}

The field data used for model calibration/validation were obtained from a field experiment carried out at Giza Agricultural Research Station farm, Egypt, (30.03 latitude, $31.13^{\circ}$ longitude, and $18.6 \mathrm{~m}$ elevation) during the winter seasons of 2018-19 and 2019-20. The selected site represents the conditions of Middle Egypt. The experiment was laid out in a split-plot design with three replicates. The plot area was $48.0 \mathrm{~m}^{2}(6 \mathrm{~m} \mathrm{x} \mathrm{8m)}$. The main plots were assigned to three irrigation interval treatments (irrigation every 21 , 28 and 35 days) and the sub-plots were assigned to three wheat cultivars namely: Giza 171, Misr 2 and Gimmiza 9. Sowing dates were 24 and 26 November in the first and second seasons, respectively. All cultural practices, including soil preparation, fertilization, weed and pest control, for wheat crop cultivation 
were followed according to the recommendation by the Ministry of Agriculture and Land Reclamation. Plant growth stages were monitored, recorded and used for model calibration. Plants were harvested on the $1^{\text {st }}$ and $3^{\text {rd }}$ of May of the two respective seasons. At harvest, the plants of each entire sub-plot were harvested in order to determine yield and yield components measurements. Traditional basin irrigation system was implemented and application of irrigation interval treatments started from the second irrigation. Data collected from Misr 2 cultivar were used to validate the AuaCrop model.

Soil samples were collected from the experimental site to determine particle size analysis (sand, silt, and clay \%) and textural class (Table 2).

Crop water consumptive use (CU) values were determined by soil samples collected from the subplots just before and $48 \mathrm{hrs}$ after each irrigation as well as at harvest. Sampling depths were taken at $15 \mathrm{~cm}$ interval down to $60 \mathrm{~cm}$ depth of the soil profile. The CU values were calculated according to Israelsen and Hansen (1962) as follows:

Where:

$$
C U=\left(\frac{Q 2-Q 1}{100}\right) * B d * D
$$

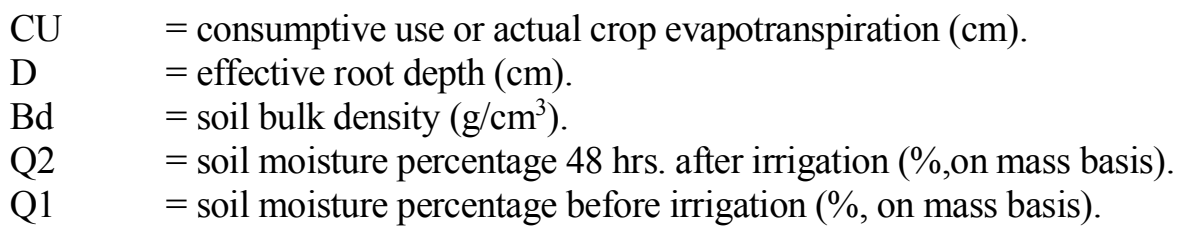

Agrometeorological data from the station located at Giza (Lat. 30:03 $3^{\circ}$ Long. $31.13^{\circ}$, and $18.6 \mathrm{~m}$ above mean sea level) were recorded. The station is $50 \mathrm{~m}$ from the experimental site. Therefore, the weather data represent the field conditions reasonably well. Average monthly weather data for the two growing seasons are presented in Table (1).

Table 1: Meteorological data at Giza Agriculture Research Station in 2018/2019 and 2019/2020 growing seasons.

\begin{tabular}{|c|c|c|c|c|c|c|c|}
\hline \multirow{2}{*}{$\begin{array}{l}\text { Season } \\
\text { Month }\end{array}$} & \multicolumn{7}{|c|}{$2018 / 2019$} \\
\hline & $\operatorname{Tmax}\left({ }^{\circ} \mathrm{C}\right)$ & Tmin & RH & $\mathbf{W S}$ & RF & SS & SR \\
\hline November & 26.9 & 15.5 & 57.7 & 1.8 & 0.0 & 10.5 & 14.6 \\
\hline December & 22.0 & 11.2 & 60.7 & 1.5 & 2.0 & 10.1 & 12.1 \\
\hline January & 19.6 & 7.0 & 51.7 & 1.6 & 0.0 & 10.3 & 13.2 \\
\hline February & 21.8 & 8.1 & 53.0 & 1.6 & 2.0 & 11.0 & 20.0 \\
\hline March & 23.7 & 12.0 & 50.0 & 2.0 & 4.0 & 11.8 & 23.6 \\
\hline April & 28.5 & 14.5 & 46.3 & 2.1 & 0.1 & 12.8 & 27.8 \\
\hline May & 35.5 & 19.0 & 25.0 & 2.3 & 0.0 & 13.5 & 30.0 \\
\hline Mean & 25.4 & 12.5 & 49.2 & 1.9 & 1.2 & 11.4 & 20.2 \\
\hline \multicolumn{8}{|c|}{$2019 / 2020$} \\
\hline November & 26.6 & 14.9 & 55.3 & 1.8 & 0.0 & 10.5 & 17.0 \\
\hline December & 22.2 & 10.8 & 60.9 & 1.8 & 3.0 & 9.2 & 15.5 \\
\hline January & 19.6 & 9.2 & 57.4 & 1.9 & 2.4 & 10.4 & 16.5 \\
\hline February & 21.2 & 9.4 & 45.3 & 1.9 & 4.8 & 11.0 & 19.7 \\
\hline March & 24.8 & 12.2 & 45.0 & 2.6 & 17.0 & 12.0 & 24.0 \\
\hline April & 29.1 & 14.3 & 34.0 & 2.0 & 0.0 & 12.8 & 27.7 \\
\hline May & 34.6 & 19.1 & 29.3 & 2.4 & 0.0 & 13.5 & 29.9 \\
\hline Mean & 25.5 & 12.8 & 46.8 & 2.1 & 3.9 & 11.3 & 21.5 \\
\hline
\end{tabular}

$\mathrm{T}$ max and $\mathrm{T} \min =$ maximum and minimum air temperatures $\left({ }^{\circ} \mathrm{C}\right) ; \mathrm{WS}=$ wind speed $(\mathrm{m} / \mathrm{sec}) ; \mathrm{RF}=$ rainfall $(\mathrm{mm}$ /month); SS = actual sun shine (h); SR = solar radiation $\left(\mathrm{cal}^{\mathrm{c}} \mathrm{cm}^{2} / \mathrm{day}\right)$.

\subsection{AquaCrop Model}

The FAO AquaCrop model is a crop growth model developed to assess the effect of environment and management on crop production. The model uses a relative small number of parameters and input variables. Inputs consist of weather data, crop characteristics for the specific cultivar and tuned to the environment, soil characteristics, and management practices that define the environment in which the 
crop will develop. The inputs are stored in climate, crop, soil and management files and can be easily retrieved (Steduto et al., 2009, and Raes et al., 2009).

In this study, the AquaCrop model was used to simulate and predict wheat biomass and grain yields, crop evapotranspiration (ETc) and water productivity (WP) under Giza region which represents Middle Egypt conditions. The model was calibrated and modified using data from field experiment described above. In the calibration process, the normalized water productivity (WP*) was set at $15 \mathrm{~g}$ $\mathrm{m}^{-2}$, biomass yield (BY) and the grain yield (GY) were calculated according Raes et al., (2018).

\subsection{AquaCrop model simulation input files}

\subsubsection{Weather Data}

AquaCrop requires minimum and maximum air temperatures, reference evapotranspiration (ETo), rainfall, and the mean annual $\mathrm{CO}_{2}$ concentration (provided in AquaCrop). The ETo is derived from weather station data by means of the FAO Penman-Monteith equation. The data presented in Table 1 were used to calculate ETo values.

\subsubsection{Soil Data:}

Soil particle size distribution and textural class of the experimental site were determined according to Page et al., (1982) and the obtained values are presented in Table 2. Soil moisture constants and saturated hydraulic conductivity (Ks) were estimated by SAPW model Saxton et al., (2006) and presented in Table 3. The obtained values were used in adjusting soil profile file (*.SOL) required for calibrating the AquaCrop model.

Table 2: Soil particle size distribution and textural class of the experimental site.

\begin{tabular}{lc}
\hline Soil fraction & Content (\%) \\
\hline Coarse sand & 2.91 \\
Fine sand & 16.40 \\
Silt & 32.41 \\
Clay & 48.28 \\
Textural class & Clay \\
\hline
\end{tabular}

Table 3: Estimated soil moisture constants, bulk density, and saturated hydraulic conductivity values of the soil at Giza Agricultural Research Station.

\begin{tabular}{|c|c|c|c|c|c|c|}
\hline \multirow{2}{*}{ Depth (cm) } & \multicolumn{3}{|c|}{ Moisture constants (\%) } & \multirow{2}{*}{$\begin{array}{c}\text { Available } \\
\text { water }(\mathbf{m m})\end{array}$} & \multirow{2}{*}{$\begin{array}{c}\text { Bulk } \\
\text { density }\left(\mathrm{g} \mathrm{cm}^{-3}\right) \\
\end{array}$} & \multirow{2}{*}{$\begin{array}{c}\text { Ksat. } \\
\left.(\mathbf{m m ~ h r})^{-1}\right)\end{array}$} \\
\hline & Field Capacity & Wilting Point & Saturation & & & \\
\hline 0-20 & 39.1 & 25.3 & 55.8 & 32.3 & 1.17 & 3.40 \\
\hline $20-40$ & 38.4 & 22.2 & 55.6 & 38.2 & 1.18 & 3.64 \\
\hline 40-70 & 34.8 & 19.9 & 54.3 & 54.1 & 1.21 & 3.91 \\
\hline
\end{tabular}

\subsubsection{Crop input data}

Crop file (*.CRO), including: cultivar selected in the study (Misr 2), sowing and harvest dates, seeding rate, plant density, and canopy cover were used. All input crop parameters used for simulation are described in Table (4). The data were stored in standard files "Wheat GDD.CRO" to be used in adjusted crop cycle and model calibration.

\subsection{Irrigation management data}

Irrigation files (*.IRR) were generated as suggested in the adaptation study scenarios. All input parameters required are presented in Table 5.

\subsection{Crop model calibration/validation}

All the data of climate, soil, crop growth, and yield collected from the two seasons were used as inputs in the standard file formats needed for execution of the model calibration. The model was validated by comparing observed data of grain and biological yield, cumulative ETc and growing season duration to the simulated values. The goodness of fit between the measured and predicted data was tested using the percent difference $(P d)$ as suggested by Wilmot (1982). Furthermore, statistics regression analysis; the coefficient of determination $\left(R^{2}\right)$ and root mean square error $(R M S E)$ were used to evaluate both calibration 
and validation results. The $P d$ and $R^{2}$ were used to access the predictive power of the model, and the RMSE indicated the error in model prediction.

Table 4: Input parameters used for crop file.

\begin{tabular}{|c|c|c|}
\hline Parameters & Value & $\begin{array}{c}\text { Way of data } \\
\text { Determination }\end{array}$ \\
\hline Seed rate & $165 \mathrm{~kg} \mathrm{ha}^{-1}$ & F \\
\hline Initial canopy cover $(\%)$ & 4.14 & $\mathrm{E}$ \\
\hline Maximum canopy cover $(\%)$ & 94 & $\mathrm{E}$ \\
\hline Base temperature $\left({ }^{0} \mathrm{C}\right)$ & 6 & $\mathrm{~L}$ \\
\hline Upper temperature $\left({ }^{0} \mathrm{C}\right)$ & 32 & $\mathrm{~L}$ \\
\hline Maximum crop coefficient value (Kc) & 1.12 & $\mathrm{~L}$ \\
\hline Harvest index (\%) & 39 & $\mathrm{~F}$ \\
\hline Canopy expansion (\% GDD) & 7.1 & E \\
\hline Canopy decline coefficient (\% GDD) & 0.38 & $\mathrm{E}$ \\
\hline Normalized water productivity WP* $\left(\mathrm{g} \mathrm{m}^{-2}\right)$ & 15.5 & $\mathrm{E}$ \\
\hline Shape factor for root expansion & 1.5 & $\mathrm{E}$ \\
\hline Maximum effective rooting depth (m) & 0.73 & $\mathrm{~F}$ \\
\hline days from sowing to emergency (day) & 9 & $\mathrm{~F}$ \\
\hline Time to reach full crop canopy (day) & 81 & $\mathrm{~F}$ \\
\hline Time to reach maximum root depth (day) & 65 & $\mathrm{~F}$ \\
\hline Time to reach flowering (day) & 93 & $\mathrm{~F}$ \\
\hline Duration of flowering (day) & 19 & $\mathrm{~F}$ \\
\hline Time to reach senescence (day) & 112 & $\mathrm{~F}$ \\
\hline Time to reach maturity (day) & 155 & $\mathrm{~F}$ \\
\hline
\end{tabular}

F: field L: Laboratory $\mathrm{E}$ : estimated

Table 5: Input parameters used for irrigation files (*IRR) and for the adaptation study.

\begin{tabular}{|c|c|c|c|c|c|c|c|}
\hline \multirow{3}{*}{$\begin{array}{l}\text { Adaptation } \\
\text { Scenarios }\end{array}$} & \multicolumn{7}{|c|}{ Irrigation system: Surface irrigation method: Basin } \\
\hline & \multicolumn{7}{|c|}{ Surface wetted by the irrigation: $100 \%$} \\
\hline & IRR21 & IRR28 & IRR35 & Far & atment & $70 \%$ of FAP & Water quality \\
\hline No of Irri. & \multicolumn{3}{|c|}{ Days after sowing } & day & \multicolumn{2}{|c|}{ Applied water (mm) } & \\
\hline Sowing & - & - & - & - & 70 & 48 & \multirow{8}{*}{$\begin{array}{c}\text { Fresh water No } \\
\text { salinity }\end{array}$} \\
\hline First & 21 & 28 & 35 & 23 & 70 & 48 & \\
\hline Second & 42 & 56 & 70 & 45 & 70 & 48 & \\
\hline Third & 63 & 84 & 105 & 66 & 70 & 48 & \\
\hline Fourth & 84 & 112 & 140 & 90 & 70 & 48 & \\
\hline Fifth & 105 & 140 & - & 111 & 70 & 48 & \\
\hline Sixth & 126 & - & - & 132 & 70 & 48 & \\
\hline Seventh & 144 & - & - & - & - & & \\
\hline
\end{tabular}

\subsection{Adaptation study}

The adaption study was conducted to determine best irrigation and sowing date scenarios that maximize yield, save irrigation water, and optimize water productivity under conditions of Middle Egypt (Giza region), and to apply the best findings of predicted results on future field trials. After verifying the accuracy of the model it was used to predict wheat yield production and ETcrop of Masir 2 variety (showed the best results in field trial) at different sowing dates: 10 and 25 November, 10 and 25 December, with five irrigation scenarios (Table 5) as follows:

$\mathrm{I}_{1}$. Irrigation every 21-day and refill soil profile to field capacity (as model suggest).

$\mathrm{I}_{2}$. Irrigation every 28 -day and refill soil profile to field capacity.

$\mathrm{I}_{3}$. Irrigation every 35 -day and refill soil profile to field capacity.

I4. Irrigation every 21-day with a fixed amount $(70 \mathrm{~mm})$ in each irrigation (farmer application).

$\mathrm{I}_{5}$. Irrigation every 21 -day with $70 \%$ of $\left(\mathrm{I}_{4}\right)$. This scenario represents the effect of water stress on the measured parameters. 


\section{Results and Discussion}

\subsection{AquaCrop validation results:}

After calibration and running simulation, the model was validated by comparing the field experiment observed grain yield (GY), biomass yield (BY), crop evapotranspiration (ETc), and growing season duration (GSD) data with simulated data. The obtained results are presented in Table 6.

Table 6: Measured and predicted grain and biomass yields, crop evapotranspiration, growing season duration, and percent difference values for Misr 2 wheat cultivar during the 2018/19 and 2019/2020 growing seasons.

\begin{tabular}{|c|c|c|c|c|c|c|}
\hline \multirow{2}{*}{ Parameters } & \multicolumn{3}{|c|}{ 2018/19 } & \multicolumn{3}{|c|}{ 2019/20 } \\
\hline & Predicted & Measured & $P d \%$ & Predicted & Measured & $P d \%$ \\
\hline Grain Yield $\left(\mathrm{t} \mathrm{ha}^{-1}\right)$ & 6.3 & 6.5 & 0.95 & 7.0 & 7.3 & 0.96 \\
\hline Biomass Yield $\left(\mathrm{t} \mathrm{ha}{ }^{-1}\right)$ & 16.7 & 17.0 & 0.99 & 16.5 & 16.5 & 1.00 \\
\hline ETc (mm) & 325.4 & 361.2 & 0.90 & 345.3 & 378.9 & 0.91 \\
\hline Growing season (day) & 155 & 158 & 0.99 & 153 & 157 & 0.96 \\
\hline
\end{tabular}

Results indicated, in general, that there was a close agreement between the observed and predicted values in the two seasons. The observed values were within 90 to $99 \%$ of the predicted values in the 1st season, and within 91 to $100 \%$ in the 2nd season. Linear regression analysis models were developed between the measured and predicted values of GY, BY, ETc, and GSD (Figs. 1 to 4). The best-fitting model was obtained with a growing session duration, where the two-season average values were $\mathrm{R}^{2}=0.98, \mathrm{RMSE}=5.23$ day, and $P d=0.98 \%$. The two-year average simulated aboveground $\mathrm{BY}$ values were similar to those measured $\left(\mathrm{R}^{2}=0.97, \mathrm{RMSE}=363 \mathrm{~kg} \mathrm{ha}^{-1}\right.$, and $\left.P d=0.99 \%\right)$. Corresponding values of wheat grain yield were $0.94,355 \mathrm{~kg} \mathrm{ha}^{-1}$ and $0.95 \%$. Results revealed also that, average statistical crop evapotranspiration (ETc) values of $\mathrm{R}^{2}$, RMSE, and $P d$ were $0.95,35 \mathrm{~mm}$, and $0.91 \%$, respectively. Higher $\mathrm{R}^{2}$ and $P d$ values and lower RMSE values indicate good model performance. These results indicate that the AquaCrop model was found to be valid in simulating winter wheat BY, GY, ETc, and GSD under the experimental conditions, and can be used in similar situations. The obtained results agreed with those reported by Heng et al., (2009) and Neha et al., (2017), who demonstrated that the AquaCrop model is a good predictor of biomass and grain yield $\mathrm{R}^{2}=0.94$, $\mathrm{RMSE}=0.27$ ton $\mathrm{ha}^{-1}$.

\subsection{Crop simulation and adaption scenarios results:}

\subsubsection{Simulated biomass yield (BY):}

Regarding irrigation interval treatments, the predicted biomass yield (BY) values (Table 6) showed a close agreement between $\left(I_{1}\right) 21$ days and $\left(I_{2}\right) 28$ days, since the BY of $I_{2}$ was less than 5\% of $\mathrm{I}_{1}$. Results showed also that, irrigating every 35 days $\left(\mathrm{I}_{3}\right)$ or applying $70 \%$ of farmer application water $\left(\mathrm{I}_{5}\right.$ ) caused biomass yield reduction of 18.5 and $20.3 \%$ (season 1) and by 25.6 and $32.3 \%$ (season two) as compared with $\mathrm{I}_{1}$ treatment.

With respect to wheat sowing dates, the predicted biomass yield results revealed that early sowing on $10^{\text {th }}$ November led to an increase in BY compared to other sowing dates in both growing seasons. The increase in BY due to $\mathrm{DS}_{1}$ reached 3.2, 7.0, and $12.7 \%$ as compared to $\mathrm{DS}_{2}, \mathrm{DS}_{3}$, and $\mathrm{DS}_{4}$, respectively in the $2018 / 19$ season. In the $2019 / 2020$ season, BY of $\mathrm{DS}_{1}$ increased by $4.2,10.2$, and $16.8 \%$ as compared with $\mathrm{DS}_{2}, \mathrm{DS}_{3}$, and $\mathrm{DS}_{4}$ sowing dates, respectively. These results agreed with that reported by Abd El-Monem (2007) and Mostafa et al., (2009). They concluded that, the exposure of wheat plants to high-temperature stress due to late cultivation could lead to reducing the vegetative and reproductive phases, and consequently reduce grain, straw and biological yields compared to plants sown at the normal date. 

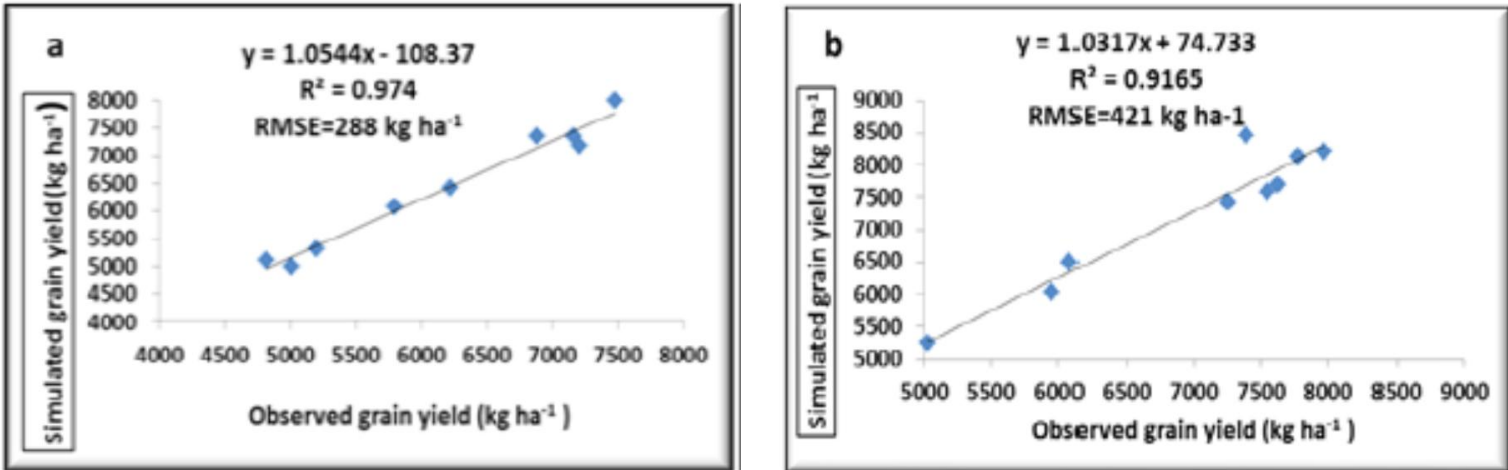

Fig. 1(a, b): Simulated grain yield $\mathrm{kg}$ has related to Observed data for 2018/2019 and 2019/2020 seasons
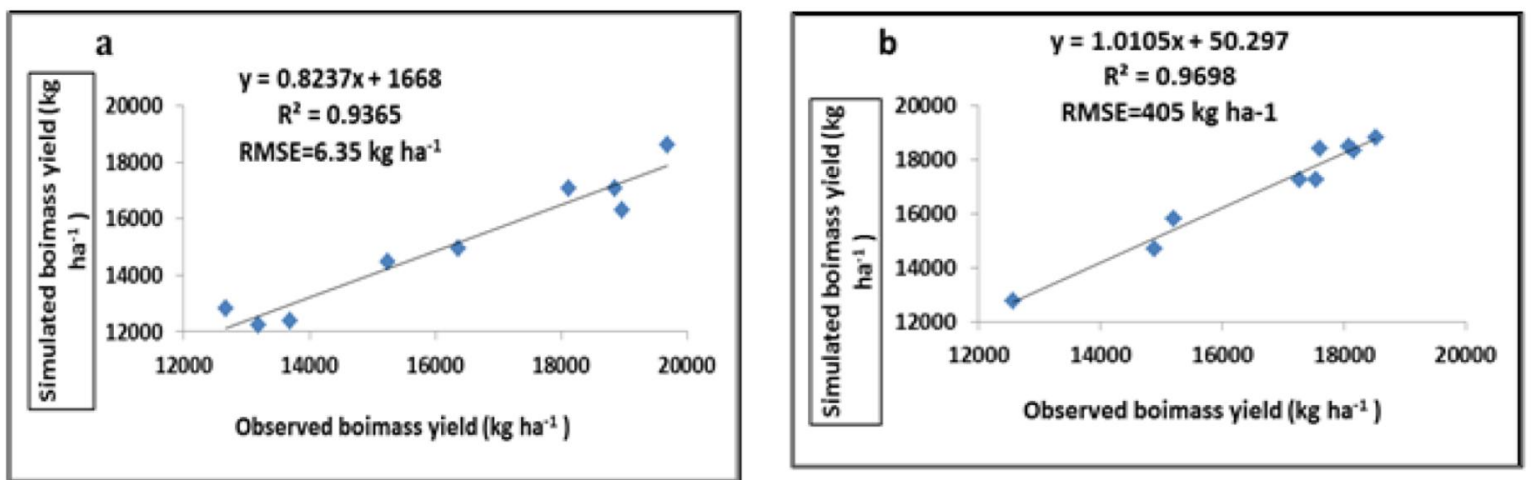

Fig. 2 (a ,b): biomass yield $\mathrm{kg} \mathrm{h}$ as related to observed data for 2018/2019 -1 and 2019/2020 seasons
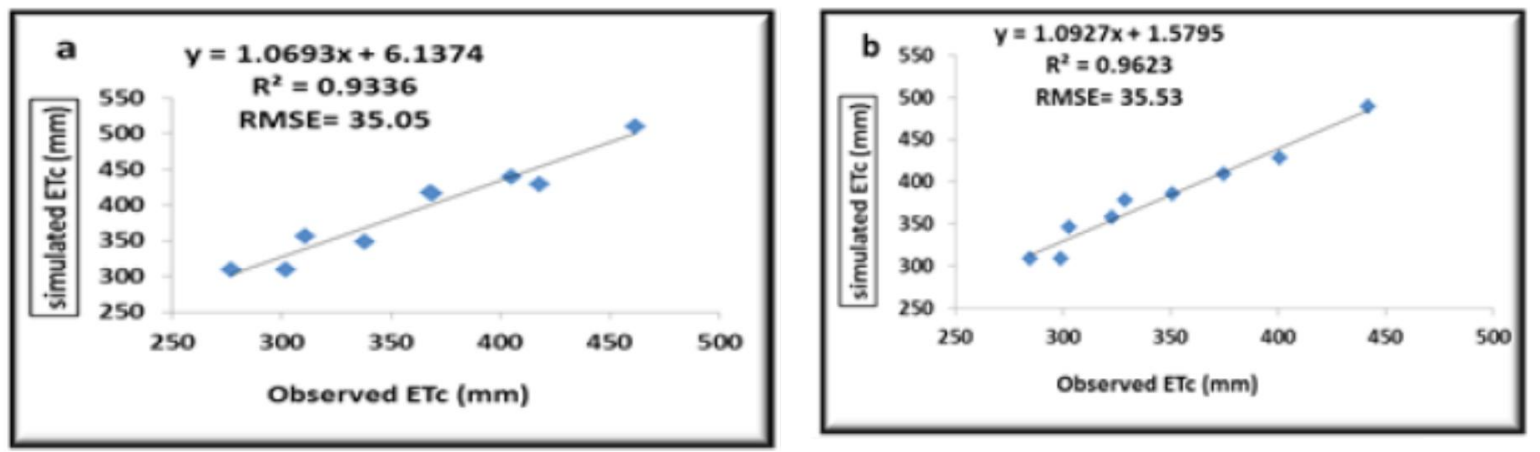

Fig. 3 (a,b): simulated crop water use (Etc $\mathrm{mm} / \mathrm{season}$ )as related to observed data for 2018/2019 and 2019/2020 season
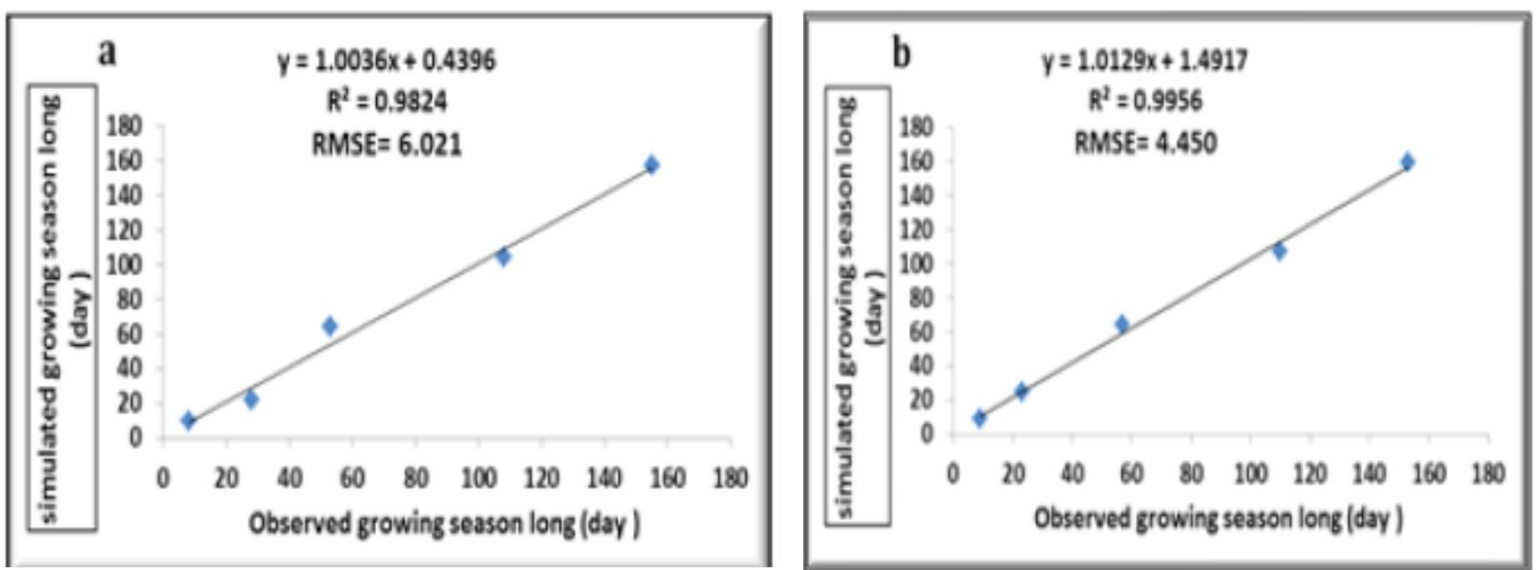

Fig. 4 (a,b): simulated growing season long(day) as related to observed data for 2009/2010 and 2010/2011 seasons 


\subsubsection{Simulated water productivity (WP):}

Results shown in Table 6 , indicated that simulated water productivity values (WP, $\mathrm{kg} \mathrm{m}^{-3}$ ) varied due to irrigation scenarios. The highest values of 1.47 and $1.54 \mathrm{~kg} \mathrm{~m}^{-3}$ were obtained under $\left(\mathrm{I}_{5}, 70 \%\right.$ farmer application amount) for seasons one and two, respectively. While irrigation every 35-day interval recorded the lowest WP values of 1.36 and $1.41 \mathrm{~kg} \mathrm{~m}^{-3}$ in $1^{\text {st }}$ and $2^{\text {nd }}$ seasons, respectively. The results are similar to those reported by Nematall et al., (2014), who found that the highest WUE value for wheat was achieved as irrigation practiced under irrigation at 0.75 evaporation pan coefficient (EPC) compared to 1.25 EPC.

Regarding sowing dates, results showed that delaying the sowing date from early November to late December decrease WP in both seasons. The highest values were 1.51 and $1.60 \mathrm{~kg} \mathrm{~m}^{-3}$ obtained from plants sown on $10^{\text {th }}$ November, while lowest values were 1.32 and $1.40 \mathrm{~kg} \mathrm{~m}^{-3}$ recorded with sowing on $25^{\text {th }}$ December in both seasons, respectively. The results are in harmony with those obtained by Duchemin et al., (2015), who found that the maximal WUE around $3.5 \mathrm{~kg} \mathrm{~m}^{-3}$ obtained with wheat crop sown the earliest compared to those sown the latest (minimal WUE around $1.5 \mathrm{kgm}^{-3}$ ).

Table 6: Simulated biomass yield $\left(\mathrm{t} \mathrm{ha}^{-1}\right)$ and water productivity $\left(\mathrm{kg} \mathrm{m}^{-3}\right)$ of wheat crop as affected by irrigation intervals and sowing dates scenarios at Giza region in 2018/19 and 2019/20 growing seasons.

\begin{tabular}{|c|c|c|c|c|c|c|c|c|c|c|c|c|}
\hline \multirow{4}{*}{$\begin{array}{l}\text { Seasons } \\
\text { Sowing date }\end{array}$} & \multicolumn{6}{|c|}{$2018 / 2019$} & \multicolumn{6}{|c|}{$2019 / 2020$} \\
\hline & \multicolumn{11}{|c|}{ Biomass yield (t ha $\left.{ }^{-1}\right)$} & \\
\hline & \multicolumn{12}{|c|}{ Irrigation Scenarios. } \\
\hline & $\mathbf{I}_{1}$ & $\mathbf{I}_{2}$ & $\mathbf{I}_{3}$ & $\mathbf{I}_{4}$ & $\mathbf{I}_{5}$ & Average & $\mathbf{I}_{1}$ & $\mathbf{I}_{2}$ & $\mathbf{I}_{3}$ & $\mathbf{I}_{4}$ & $\mathbf{I}_{5}$ & Average \\
\hline$\overline{\text { SD }_{1}}$ & 16.5 & 16.2 & 14.1 & 15.7 & 14.1 & 15.3 & 17.5 & 17.2 & 14.5 & 16.6 & 14.1 & 16.7 \\
\hline $\mathrm{SD}_{2}$ & 16.3 & 15.8 & 13.6 & 14.8 & 13.7 & 14.8 & 17.4 & 16.7 & 14.2 & 15.6 & 13.1 & 16.0 \\
\hline $\mathrm{SD}_{3}$ & 15.9 & 14.9 & 13.4 & 13.7 & 13.2 & 14.2 & 17.2 & 15.7 & 13.6 & 14.5 & 12.7 & 15.0 \\
\hline $\mathrm{SD}_{4}$ & 15.2 & 14.1 & 12.7 & 12.3 & 12.1 & 13.3 & 16.7 & 14.7 & 12.4 & 13.0 & 12.2 & 13.9 \\
\hline Average & 16.0 & 15.3 & 13.5 & 14.1 & 13.3 & 14.4 & 17.2 & 16.1 & 13.7 & 14.9 & 13.0 & 15.4 \\
\hline \multicolumn{13}{|c|}{ Water productivity $\left(\mathrm{kg} \mathrm{m}^{-3}\right)$} \\
\hline SD $_{1}$ & 1.50 & 1.53 & 1.48 & 1.50 & 1.55 & 1.51 & 1.59 & 1.62 & 1.57 & 1.61 & 1.63 & 1.60 \\
\hline SD2 $_{2}$ & 1.49 & 1.51 & 1.36 & 1.48 & 1.52 & 1.47 & 1.55 & 1.56 & 1.56 & 1.56 & 1.57 & 1.56 \\
\hline $\mathrm{SD}_{3}$ & 1.41 & 1.44 & 1.32 & 1.42 & 1.46 & 1.41 & 1.49 & 1.49 & 1.40 & 1.51 & 1.54 & 1.49 \\
\hline $\mathrm{SD}_{4}$ & 1.33 & 1.34 & 1.28 & 1.32 & 1.35 & 1.32 & 1.39 & 1.41 & 1.39 & 1.41 & 1.42 & 1.40 \\
\hline Average & 1.43 & 1.46 & 1.36 & 1.43 & 1.47 & 1.43 & 1.51 & 1.52 & 1.48 & 1.52 & 1.54 & 1.51 \\
\hline
\end{tabular}

$\mathrm{I}_{1}, \mathrm{I}_{2}$, and $\mathrm{I}_{3}$ are 21,28 and 35 day interval, and $\mathrm{I}_{4}$; traditional farmer irrigation, and $\mathrm{I}_{5} 70 \%$ of $\mathrm{I}_{4} . \mathrm{SD}_{1}, \mathrm{SD}_{2}, \mathrm{SD}_{3}$ and $\mathrm{SD}_{4}$ are sowing at $10^{\text {th }}, 25^{\text {th }}$ November, $10^{\text {th }}$ and $25^{\text {th }}$ December .

\subsubsection{Simulated grain yields (GY)}

The predicted grain yield values (Table 7) increased positively with increased irrigation frequency and amounts of applied water. The short irrigation interval 21 days $\left(\mathrm{I}_{1}\right)$ recorded the highest values in both seasons. The increases in GY for $\mathrm{I}_{1}$ reached 6.2, 20.2, 13.7, and $18.4 \%$ as compared with $\left(\mathrm{I}_{2}\right) 28$ day, $\left(\mathrm{I}_{3}\right) 35$ day, $\left(\mathrm{I}_{4}\right)$ farmer application, and $\left(\mathrm{I}_{5}\right) 70 \%$ of farmer application treatments, respectively in the $1^{\text {st }}$ season. In season two, corresponding values were $4.8,17.2,10.5$, and $15.5 \%$. Results of the two growing seasons pointed clearly to the effect of increasing irrigation period and/or water stress condition, generally led to yield reduction by about $25 \%$.

Concerning the effect of sowing dates, results of predicted grain yield confirmed the priority of early sowing on $10^{\text {th }}$ November which led to an increase in GY compared to other sowing dates. This trend was true in both growing seasons with an overall two season average increase in $\mathrm{DS}_{1}$ of 6.0, 14.0, and $25.5 \%$ as compared to $\mathrm{DS}_{2}, \mathrm{DS}_{3}$ and $\mathrm{DS}_{4}$, respectively. Contrary to this, delaying sowing wheat from adopted sowing date $\left(25^{\text {th }}\right.$ November till to the $10^{\text {th }}$ and $25^{\text {th }}$ December reduced grain yield by 7.5 and $16.2 \%$ (season 1 ) and by 7.0 and $15.2 \%$ (season two), respectively.

The most effective interaction was noted with irrigating crop at 21 days interval combined with sowing it at $10^{\text {th }}$ Novembers. The obtained results indicated the role of sufficient soil water content and suitable weather conditions, especially temperature on plant growth and crop production. These results were in agreement with those reported by Eldey et al., (2018), who noticed that sowing wheat crop on $15^{\text {th }}$ November obtained maximum grain yield compared to sowing in October or December. Also, 
Meena et al., (2016) reported that wheat grain can be maintained by sowing it from $1^{\text {st }}$ till midNovember with irrigation scheduling up to $50 \%$ depletion of available soil moisture.

\subsubsection{Water saving and yield reduction:}

The main purpose of adaptation scenarios is to determine the best scenario that decreases amounts of irrigation water with the least possible crop reduction. Results recorded in Table (7) and Figs. 5 and 6 showed, in general, that water saved (WS, \%) is more than yield reduction (YD, \%) under each irrigation treatment for all sowing dates (Fig. 5). The maximum averages WS were 36.7 and $47.6 \%$ recorded under irrigation at $70 \%$ of farmer application $\left(I_{5}\right)$ for seasons one and two, respectively.

Table 7: Simulated wheat grain yields $\left(\mathrm{t} \mathrm{ha}^{-1}\right)$, irrigation water depths $(\mathrm{mm})$, and the calculated difference percentage values as affected by irrigation interval and sowing date scenarios at Giza region in 2018/2019 and 2019/2020 seasons.

\begin{tabular}{|c|c|c|c|c|c|c|c|c|c|c|c|c|}
\hline \multirow{3}{*}{$\begin{array}{l}\text { Seasons } \\
\text { Irrig. } \\
\text { Dates }\end{array}$} & \multicolumn{6}{|c|}{$2018 / 2019$} & \multicolumn{6}{|c|}{ 2018/2019 } \\
\hline & \multicolumn{12}{|c|}{ Grain yield $\left(\mathrm{t} \mathrm{ha}^{-1}\right)$} \\
\hline & $\mathbf{I}_{1}$ & $\mathbf{I}_{2}$ & $I_{3}$ & $I_{4}$ & $I_{5}$ & Ave. & $I_{1}$ & $\mathbf{I}_{2}$ & $\mathbf{I}_{3}$ & $I_{4}$ & $I_{5}$ & Ave. \\
\hline SD $_{1}$ & 7.98 & 7.76 & 7.09 & 7.52 & 7.2 & 7.51 & 8.45 & 8.26 & 7.87 & 8.36 & 8.00 & 8.19 \\
\hline $\mathrm{SD}_{2}$ & 7.82 & 7.53 & 6.46 & 6.91 & 6.61 & 7.07 & 8.41 & 8.08 & 7.18 & 7.68 & 7.34 & 7.74 \\
\hline $\mathrm{SD}_{3}$ & 7.61 & 7.08 & 5.78 & 6.34 & 5.95 & 6.55 & 8.17 & 7.76 & 6.43 & 7.04 & 6.61 & 7.20 \\
\hline $\mathrm{SD}_{4}$ & 7.24 & 6.43 & 5.13 & 5.67 & 5.25 & 5.94 & 7.79 & 7.19 & 5.70 & 6.30 & 5.83 & 6.56 \\
\hline Average & 7.66 & 7.20 & 6.12 & 6.61 & 6.25 & 6.77 & 8.21 & 7.82 & 6.80 & 7.35 & 6.95 & 7.42 \\
\hline \multicolumn{13}{|c|}{ Reduction (\%) in grain yield as related to irrigation treatments } \\
\hline & & $\mathbf{I}_{1} / \mathbf{I}_{2}$ & $\mathbf{I}_{1} / \mathbf{I}_{3}$ & $\mathbf{I}_{1} / \mathbf{I}_{4}$ & $\mathbf{I}_{1} / \mathbf{I}_{5}$ & Ave. & & $\mathbf{I}_{1} / \mathbf{I}_{2}$ & $\mathbf{I}_{1} / \mathbf{I}_{3}$ & $\mathbf{I}_{1} / \mathbf{I}_{4}$ & $\mathbf{I}_{1} / \mathbf{I}_{5}$ & Ave. \\
\hline SD1 & & 2.8 & 11.2 & 5.8 & 9.8 & 7.4 & & 2.2 & 7 & 1.1 & 5.4 & 3.3 \\
\hline SD2 & & 3.7 & 17.4 & 11.6 & 15.5 & 12.1 & & 3.9 & 15.2 & 10.2 & 13.9 & 9.1 \\
\hline SD3 & & 7 & 24 & 16.7 & 21.8 & 17.4 & & 5 & 22.4 & 17.6 & 22.2 & 14.7 \\
\hline SD4 & & 11.3 & 29.3 & 21.8 & 27.6 & 22.5 & & 7.7 & 29.1 & 26.1 & 31.1 & 21.1 \\
\hline Average & & 6.2 & 20.5 & 14.0 & 18.7 & 14.9 & & 4.7 & 18.4 & 13.8 & 18.2 & 12.1 \\
\hline \multicolumn{13}{|c|}{ Reduction (\%) in grain yield as related to sowing dates } \\
\hline SD1/SD2 & 2.0 & 3.1 & 9.8 & 8.8 & 8.9 & 6.5 & 0.5 & 2.2 & 9.6 & 8.9 & 9.0 & 6.0 \\
\hline SD3/SD2 & -2.7 & -6.0 & -10.5 & -8.2 & -10.0 & -7.5 & -2.9 & -4.0 & -10.4 & -8.3 & -9.9 & -7.1 \\
\hline SD4/SD2 & -7.4 & -14.6 & -20.6 & -17.9 & -20.6 & -16.2 & -7.4 & -11.0 & -20.6 & -18.0 & -20.6 & -15.5 \\
\hline & \multicolumn{12}{|c|}{ Irrigation water amount $\left(\mathrm{mm}\right.$ season $\left.^{-1}\right)$} \\
\hline SD1 & 484 & 416 & 386 & 475 & 335 & 431 & 504 & 449 & 419 & 475 & 335 & 448 \\
\hline SD2 & 509 & 452 & 403 & 475 & 335 & 447 & 558 & 480 & 440 & 475 & 335 & 470 \\
\hline SD3 & 556 & 488 & 428 & 475 & 335 & 468 & 607 & 518 & 465 & 475 & 335 & 492 \\
\hline SD4 & 612 & 560 & 434 & 475 & 335 & 490 & 662 & 556 & 479 & 475 & 335 & 507 \\
\hline Average & 540 & 479 & 413 & 475 & 335 & 459 & 583 & 501 & 451 & 475 & 335 & 479 \\
\hline \multicolumn{13}{|c|}{ Reduction (\%) in irrigation water as related to irrigation treatments } \\
\hline & & $\mathbf{I}_{1} / \mathbf{I}_{2}$ & $\mathbf{I}_{1} / \mathbf{I}_{3}$ & $\mathbf{I}_{1} / \mathbf{I}_{4}$ & $\mathbf{I}_{1} / \mathbf{I}_{5}$ & Ave. & & $\mathbf{I}_{1} / \mathbf{I}_{2}$ & $\mathbf{I}_{1} / \mathbf{I}_{3}$ & $\mathbf{I}_{1} / \mathbf{I}_{4}$ & $\mathbf{I}_{1} / \mathbf{I}_{5}$ & Ave. \\
\hline SD $_{1}$ & & 14.0 & 20.2 & -1.2 & 30.8 & 16.0 & & 10.8 & 16.7 & 2.8 & 33.3 & 11.0 \\
\hline $\mathrm{SD}_{2}$ & & 11.2 & 20.8 & 3.7 & 34.2 & 17.5 & & 14.0 & 21.1 & 12.2 & 40.0 & 15.8 \\
\hline $\mathrm{SD}_{3}$ & & 12.2 & 23.0 & 11.9 & 39.7 & 21.7 & & 14.7 & 23.4 & 19.3 & 44.8 & 18.9 \\
\hline $\mathrm{SD}_{4}$ & & 8.5 & 29.1 & 19.9 & 45.3 & 25.7 & & 16.0 & 27.6 & 26.0 & 49.4 & 23.4 \\
\hline Average & & 11.5 & 23.3 & 8.6 & 37.5 & 20.2 & & 13.9 & 22.2 & 15.0 & 41.9 & 17.3 \\
\hline \multicolumn{13}{|c|}{ Reduction (\%) in irrigation water as related to sowing dates } \\
\hline $\mathrm{SD}_{1} / \mathbf{S D}_{2}$ & -4.9 & -8 & -4.2 & 0.0 & 0.0 & -5.7 & -9.7 & $-6.5^{8}$ & -4.8 & 0.0 & 0.0 & -7.0 \\
\hline $\mathrm{SD}_{3} / \mathbf{S D}_{2}$ & 9.2 & 8 & 6.2 & 0.0 & 0.0 & 7.8 & 8.8 & 7.9 & 5.7 & 0.0 & 0.0 & 7.5 \\
\hline $\mathrm{SD}_{4} / \mathrm{SD}_{2}$ & 20.2 & 19.5 & 7.7 & 0.0 & 0.0 & 15.8 & 18.6 & 15.8 & 8.9 & 0.0 & 0.0 & 14.4 \\
\hline Average & 8.2 & 6.5 & 3.2 & 0.0 & 0.0 & 6.0 & 5.9 & 5.8 & 3.3 & 0.0 & 0.0 & 5.0 \\
\hline
\end{tabular}

Where: $\mathrm{DS}_{1}, \mathrm{DS}_{2}, \mathrm{DS}_{3}$ and $\mathrm{DS}_{4}=$ sowing on $10^{\text {th }}$ and $25^{\text {th }}$ November, $10^{\text {th }}$ December and $25^{\text {th }}$ December , respectively and $\mathrm{I}_{1}$ to $\mathrm{I}_{5}$; refer to Irrigation application scenarios

Corresponding values of yield reduction under the same irrigation scenario were 20.6 and $18.1 \%$ for the respective seasons. Whereas, the minimum WS of 13.0 and $16.4 \%$ were registered with 28 days $\left(\mathrm{I}_{2}\right)$ in both seasons. Corresponding yield reduction for $\left(\mathrm{I}_{2}\right)$ was $7.4 \%$ for both seasons. It was noted also that, maximum $\mathrm{YD}$ was recorded with $\left(\mathrm{I}_{3}\right) 35$-day interval treatment. This may be due to the fact that plants under long irrigation period suffer from deficit water and high soil moisture tension, as well as high osmotic pressure in plant cell especially if it was compiled with heat stress which reflects high temperature and cause damage in plant growth components and decrease in final yield at late sowing date. 
In is clear from the results that, implementing deficit irrigation strategies under full management may be beneficial in maximizing water save with minimal yield reduction, moreover the short interval irrigation with less water amount (scenario $\mathrm{I}_{5}$ ) is more effective than irrigation at long intervals, even if the soil profile is refilled to field capacity (scenario $\mathrm{I}_{3}$ ).

Regarding sowing dates, results indicated that sowing wheat crop in 10 November decreased irrigation water and maximized yield as compared to other tested sowing dates (Table 7 and Figs. 5 and 6). The water saved at this date ranged from 4.2 to $9.7 \%$ with $I_{1}$ to $I_{3}$ scenarios, whereas $0.0 \%$ at $I_{4}$ and $\mathrm{I}_{5}$ related to constant amount of irrigation water applied for all sowing dates. The corresponding yield increased at this date ranged from $0.5 \%$ under normal conditions $\left(\mathrm{I}_{1}\right)$ to $9.8 \%$ under water stress $\left(\mathrm{I}_{3}\right)$ for both seasons. On the other hand, delaying the sowing date to 10 and 25 December caused an increase in ETc and decrease in grain yield (GY) under all irrigation scenarios. The increased percentage in Etc ranged from 5.7 to $9.2 \%$ for $10^{\text {th }}$ December date $\left(\mathrm{DS}_{3}\right)$ and from 7.7 to $20.2 \%$ for $25^{\text {th }}$ December $\left(\mathrm{DS}_{4}\right)$, respectively. Parallel GY reduction percentage ranged from 2.7 to $10.5 \%$ with $\left(\mathrm{DS}_{3}\right)$ and from 7.4 to $20.7 \%$ for $\left(\mathrm{DS}_{3}\right)$, respectively.

The results of the two season showed that the best sowing date minimizes irrigation water and maximizes yield was $10^{\text {th }}$ November.

Moreover, the best interaction was found under this sowing date with $\mathrm{I}_{2}$ (28 days interval), which allowed to save $16.6 \%$ irrigation water and increased grain yield by $2.8 \%$ as an average of both seasons

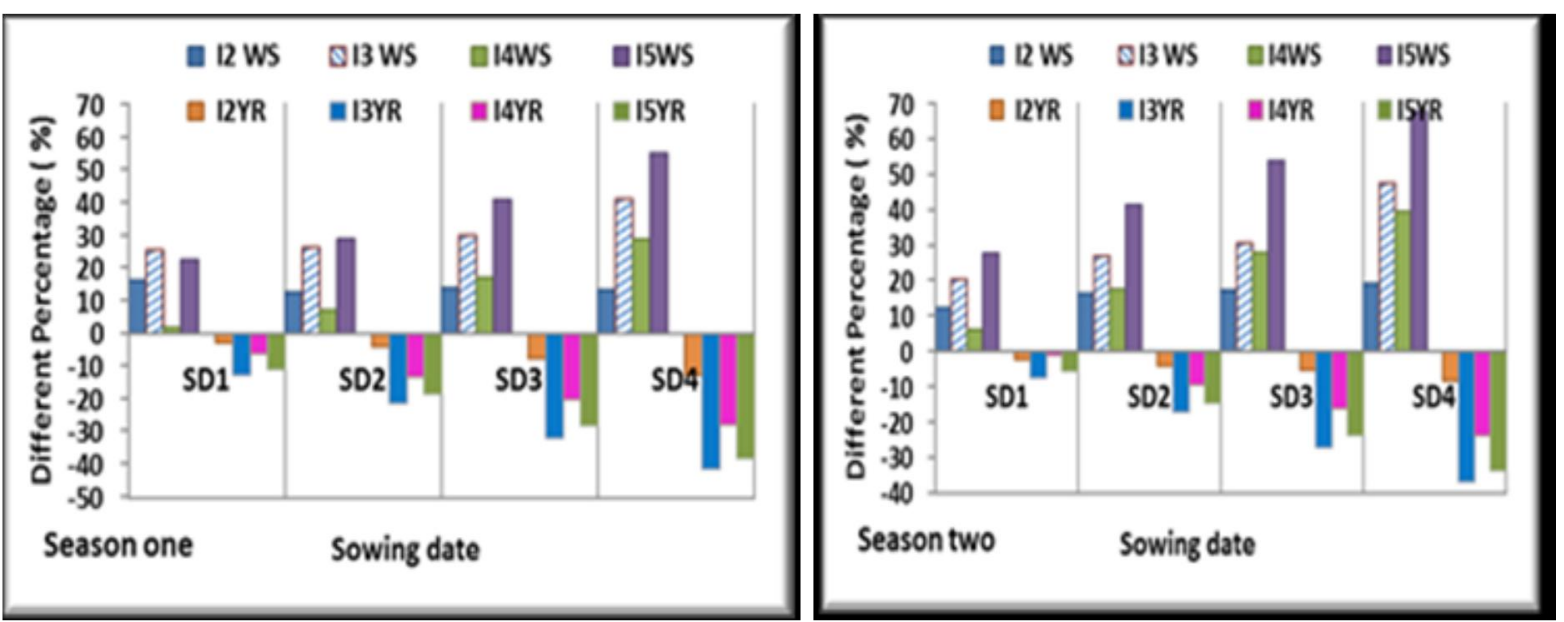

Fig. 5: Water saved related to yield reduction of wheat crop under different sowing date and irrigation scenarios at both growing seasons
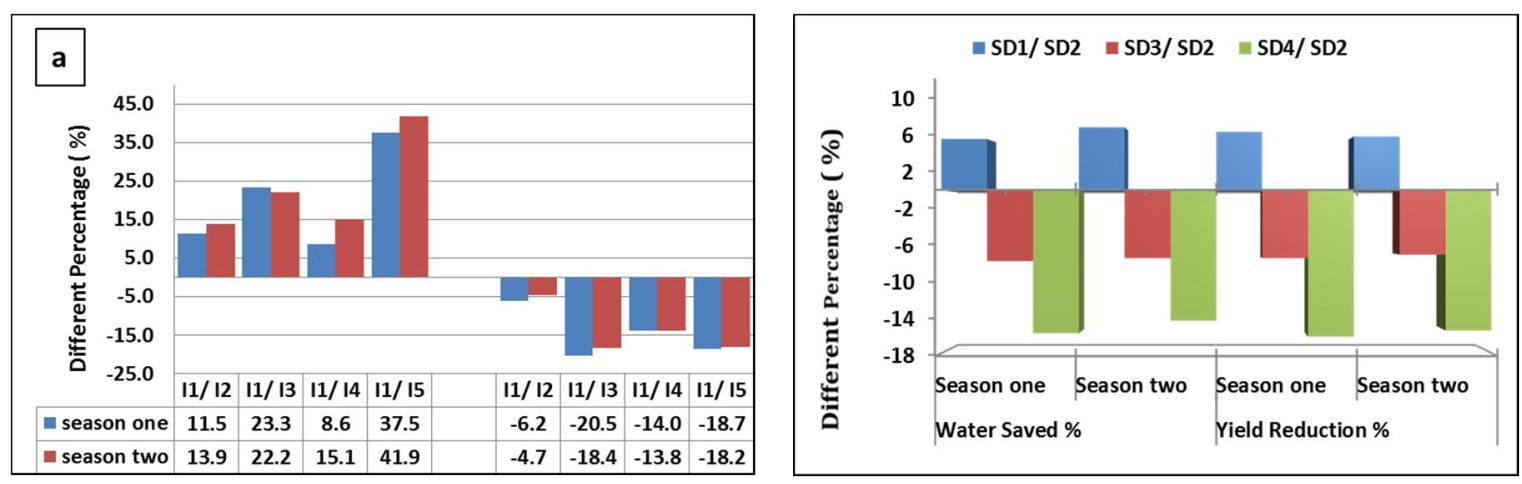

Fig. 6: Seasonal water saved in related to yield reduction of wheat crop under different irrigation scenarios' "a" and at different sowing dates "b" for both season. 


\section{Conclusion}

The current study evaluated the performance of AquaCrop model in simulating biomass and grain yield productivity of wheat crop at Giza region (Middle Egypt). A field experimental data were used in the calibration process. The results of the study suggest that:

- AquaCrop model is able to predict crop biomass and grain yields, and crop water use with acceptable accuracy.

- The adaptation study using the AquaCrop model reflected good performance in evaluating irrigation interval, sowing date scenarios, as a strategy that may be applied by the farmers. Adopting an irrigation interval of 28 days and sowing dates from 10 till 20 November ill increase the grain yield and save about $16 \%$ of irrigation water.

- It could be concluded that AquaCrop model can be used as a useful tool to help decision making for irrigation management and selecting proper sowing dates to optimize wheat yield. Also, the application of the parameters determined in this study needs to be tested for other wheat cultivars, environments and management scenarios.

\section{References}

Abd El-Monem, A.A., 2007. Polyamines as modulators of wheat growth, metabolism and reproductive development under high temperature stress. PhD Thesis: Ain Shamas University (Cairo, Egypt).

Andarzian, B., M. Bannayan, P. Steduto, H. Mazraeh, M.E. Barati, M.A. Barati, and A. Rahnama , 2011.Validation and testing of the AquaCrop model under full and deficit irrigated wheat production in Iran. Agric. Water Manag. 100: 1-8. [CrossRef]

Ano, M.A., 2007. Deficit irrigation for reducing agricultural water use. J. Experimental Botany, 58(2):147-159. doi:10.1093/jxb/erl165.

Behera, S.K., and R.K. Panda, 2009. Integrated management of irrigation water and fertilizers for wheat crop using field experiments and simulation modeling. Agric. Water Manag. 96: 1532-1540.

Cao, H.X., S.Z. Kang, and H. He, 2003. Effects of evaporation and irrigation frequency on soil water distribution, Trans. CSAE (19): 1-4.DOI:10.1016/j.agwat.2009.0409

Duchemin, B., R. Fieuzal, M.A. Rivera, J. Ezzahar, L. Jarlan, J.C. Rodriguez, O. Hagolle, and C. Watts, 2015. Impact of Sowing Date on Yield and Water Use Efficiency of Wheat Analyzed through Spatial Modeling and FORMOSAT2 Images. Remote Sensing. 7(5):59515979.https://doi.org/10.3390/rs7050595.

Eldey, E.M., A.M. El Naim, M.K. Abdelrahman, and A.I. Adam, 2018. Effect of Sowing Dates and Cultivars on Seed Yield of Wheat (Triticum aestivum L.) in New Halfa Eastern Sudan" Inte. J. of Research Studies in Agri. Sci. (IJRSAS), 4(11):.34-39, http://dx.doi.org/10.20431/24546224.04011005

Eman, I. El-Sarag and R.I.M. Ismaeil, 2013. Evaluation of some bread wheat cultivars productivity as Affected by Sowing dates and water stress in semi-arid region. Asian J. of crop science 5(2):167178.10.3923/ajcs.2013.167.178

Farre, F. and J.M. Faci, 2009. Deficit irrigation in maize for reducing agricultural water use in a Mediterranean environment. Agriculture Water Management. 96: 384-394.

Fereres E, J. Sori El-Kharraz, A. El-Sadek, N. Ghaffour, and E. Mino, 2012. Water scarcity and drought in WANA countries. Procedia Engineering. 33. 14-29. 10.1016/j.proeng.2012.01.1172.

Food and Agricultural Organization of the United Nations (FAO) Aquastat Query, 2017. http://www.fao.org/nr/water/aquastat/countries_regions/Profile_segments/EGY-WU_eng.stm.

Geerts S., and D. Raes, 2009. Deficit irrigation as an on-farm strategy to maximize crop water production in dry areas. J. Agricultural Water Management, 96(9):12751284.

Heng, L. K., T. C. Hsiao, S. Evett, T. Howell and P. Steduto, 2009. Validating the FAO AquaCrop model for irrigated and water deficient field maize. Agronomy Journal, 101(3): 488-498.

Israelson, O.W. and V.E. Hansen, 1962. Irrigation Principals and Practice. 3rd Ed. John Wiley and Sons Inc., New York, USA.

Jin X-1, H.k. Feng, X.K. Zhu, Z.h. Li, S-N. Song, X.Y. Song, 2014. Assessment of the AquaCrop Model for Use in Simulation of Irrigated Winter Wheat Canopy Cover, Biomass, and Grain Yield in the North China Plain. PLoS ONE 9(1): 
Liu, M.X., J.S. Yang, X.M. Li, M. Yu, and J. Wang, 2011. Effects of irrigation amount and frequency on soil water distribution and water use efficiency in a cotton field under mulched drip irrigation, Chin. J. Appl. Ecol., (22): 3203-3210.

McGill, J., Prikhodko, D., B.Sterk and P. Talks. 2015. "Egypt Wheat Sector Review.”. Country Highlights, FAO Investment Centre. FAO, and EBRD (European Bank for Reconstruction and Development).Organization (FAO).

Meena, R., S.S. Parihar, M. Singh and M. Khanna, 2016. Effects of sowing dates and irrigation regimes on grain quality of wheat grown under semi-arid condition of India. J. of Applied and Natural Science. (8):960-966.

Mkhabela, M.S and R.B. Paul, 2012. Performance of the FAO AquaCrop model for wheat grain yield and soil moisture simulation in Western Canada. Agric. Water Manag.,110, 16-24. [CrossRef]

Mostafa H.A.M., R.A. Hassanein, S.I. Khalil, S.A. El-Khawas, H.M.S. El-Bassiouny and A.A. Abd ElMonem, 2009. Effect of arginine or putrescine on growth, yield and yield components of late sowing wheat. In: J. of Applied Sci. Res., (6):177-183.

Neha P., R. Sumana, S. Soupayan and A.S Nain, 2017. Calibration \& validation of Aquacrop model for wheat crop in Tarai region of Uttarakhand. Journal of Pharmacognosy and Phytochemistry; 6(5): $1442-1445$

Nemait Allah, Y.O., H.M. Salem and Rania, G.M. Helal, 2014. Effect of Irrigation Scheduling and Sowing Date and Water Relation, Yield Components for Wheat Crop Grown in Middle Egypt (Giza Region) J. Soil Sci. and Agric. Eng., Mansoura Univ.,5 (12):1607-1622.

Page, A.L., R.H. Miller and D.R. Keeney, 1982. Methods of Soil Analysis. Part 2: Chemical and Microbiological Properties. Second Edition, Amer Soc. of Agron. Madison, Wisconsin, USA.

Raes D, P. Steduto, T.C. Hsiao, E. Fereres, 2018. FAO crop-water productivity model to simulate yield response to water, FAO AquaCrop Version 6.0 - 6.1, Reference Manual. Chapter, 1 (7):1-19.

Raes, D., P. Steduto, T.C. Hsiao, and E. Fereres, 2009. AquaCrop - The FAO crop model to simulate yield response to water, 1. Main algorithms and software description. Agronomy Journal, 101:4438-4447.

Saxton, K.E., and P.H. Willey, 2006. The SPAW model for agricultural field and pond hydrologic simulation. p. 401-435. In V.P. activity and effects of land management. Soil Sci. Soc. Am. J. 48: 699-702.

Shideed, K.H., F. Shomo, and A. Aw-Hassan, 2010. Population Growth and Trends in Food Production and Consumption in the CWANA Region Chapter 69 in Handbook of Agricultural Economics. (4):3531-3570.

Steduto, P., T.C. Hsiao, D. Raes and E. Fereres, 2009. AquaCrop The FAO crop model to simulate yield response to water, 1. Concepts and underlying principles. Agronomy Journal, 101:426-437.

Stockle, C.O., M. Donatelli and R. Nelson, 2003. CropSyst, a cropping systems simulation model. Eur. J. Agron. (18): 289-307.

Tellioglu, I., and P. Konandreas, 2017. Agricultural Policies, Trade and Sustainable Development in Egypt. Geneva: International Centre for Trade and Sustainable Development (ICTSD) and Rome: United Nations Food and Agriculture

Toumi, J., S. Er-Raki, Ezzahar, J.S. Khabba, L. Jarlan, and A. Chehbouni, .2016. Performance assessment of AquaCrop model for estimating evapotranspiration, soil water content and grain yield of winter wheat in Tensift Al Haouz (Morocco): Application to irrigation management. Agric. Water Manag. 163, 219-235. [CrossRef]

Wang, F.X., Y.H. Kang, and S.P. Liu, 2006. Effects of drip irrigation frequency on soil wetting pattern and potato growth in North China Plain. Agric. Water Manag. J. 79(3):248-264. DOI: 10.1016/j.agwat.2005.02.016

Willmott, C.J., 1982. Some Comments on the Evaluation of Model Performance. Bulletin of the American Meteorological Society, 63, 1309-1313. http://dx.doi.org/10.1175/1520-0477. 